\title{
Safe Spaces: Gay-Straight Alliances in High Schools*
}

\author{
Tina Fetner, Athena Elafros, Sandra Bortolin and Coralee Drechsler \\ McMaster University
}

\begin{abstract}
In activists' circles as in sociology, the concept "safe space" has been applied to all sorts of programs, organizations, and practices. However, few studies have specified clearly what safe spaces are and how they support the people who occupy them. In this paper, we examine one social location typically understood to be a safe space: gay-straight alliance groups in high schools. Using qualitative interviews with young adults in the United States and Canada who have participated in gay-straight alliances, we examine the experiences of safe spaces in these groups. We unpack this complex concept to consider some of the dimensions along which safe spaces might vary. Participants identified several types of safe space, and from their observations we derive three inter-related dimensions of safe space: social context, membership and activity.

Dans les groupes militants comme dans la pratique sociologique, l'idée d'un espace sécuritaire (« safe space ») a été utilisée pour décrire une multitude de programmes, d'organisations et de pratiques. Malheureusement, trop peu d'études ont défini clairement les caractéristiques de ces espaces sécuritaires et la manière dont ils soutiennent ceux qui les occupent. Nous examinerons ici une organisation universellement reconnue pour sa promotion du concept d'espace sécuritaire : les groupes d'alliance homosexuelle-hétérosexuelle («Gay-Straight Alliance ») implantés dans les écoles secondaires. Au travers d'entretiens approfondis avec des adolescents Canadiens et Américains ayant participé à ce type d'organisations, nous examinerons comment certains facteurs peuvent modifier les contours de cet espace sécuritaire. Les entretiens avec les participants nous ont permis d'identifier trois caractéristiques interreliées à l'idée d'espace sécuritaire : le contexte social, l'appartenance et l'action.
\end{abstract}

*This project was supported by the Social Sciences and Humanities Research Council of Canada, Standard Research Grant \# 410-2006-1385. We gratefully acknowledge the helpful comments of Jessica Fields and the anonymous reviewers of the Canadian Review of Sociology. We thank our research assistants: Zack Ambridge, Jen Harper, Ian Manley, Joanna Marks, and Leah Pearl. Earlier versions were presented at the annual meetings of the Canadian Sociological Association and the American Sociological Association. Finally, we would like to thank our research participants for their time, energy and insights. Direct correspondence to Dr. Tina Fetner, Associate Professor, Sociology Department, McMaster University, 1280 Main Street West, Hamilton, ON L8S 4M4. Email: tina.fetner@mcmaster.ca. 


\section{Introduction}

The idea of building "safe spaces" for vulnerable groups is a common-sense notion that recognizes the negative consequences of social isolation and marginalization. Among those working with adolescents, the need for safe space for youth is widely recognized (Cruz, 2008; Griffin, et al., 2004; Lee, 2002). While it is common for advocates to claim that safe spaces are necessary both for adolescent development and for activism, some scholars argue that the lack of specificity in this concept undermines researchers' ability to understand the qualities of safe spaces and the mechanisms through which social and cultural supports are passed on to group members (e.g., Polletta, 1999). In this paper, we improve the conceptual clarity of safe spaces through a qualitative analysis of one case: gay-straight alliance groups in high schools.

Gay-straight alliances are a form of social support for lesbian, gay, bisexual, transgender, and questioning (LGBTQ) high-school students that emerged in the late 1980s and early 1990s. These alliances are generally student-run social clubs akin to other high-school social groups, such as drama clubs, math teams, or yearbook clubs. However, one of the main purposes of gaystraight alliances is to provide support to LGBTQ students in difficult personal circumstances or in hostile school environments, and to advocate for LGBTQ students. Many consider gaystraight alliances to be part of the larger LGBTQ movement (e.g., Cortese, 2006; Miceli, 2005). Over the last two decades, gay-straight alliances have spread throughout high schools across North America, with the aid of the internet and several social movement organizations (see Fetner and Kush, 2008 for a discussion of patterns of emergence). This type of student group has been touted as a potential haven in a hostile world (e.g., Cortese, 2006; Hatzenbuehler, 2011). However, little research has explored how students themselves experience these groups and the 
spaces they create as supportive or safe. Nor have scholars identified the particular aspects or dimensions of social spaces that offer a sense of safety or security.

In sociology, safe spaces have been given deep attention in the literature on social movements and activism. Several terms have been used to capture this concept, such as "free spaces" and "havens," among others. In particular, social movement scholars use these terms to discern the spatial and social requirements for creating, elaborating upon, and maintaining heterodox ideas about social justice, the value of marginalized groups, and the call for social change (Evans and Boyte, 1986; Robnett, 1997). Safe spaces have been credited with producing radical identities, training movement leaders, and allowing for the development of counterhegemonic ideologies (Morris, 1984; Whittier, 1995). However, it is not altogether clear what counts as a safe space and whether these spaces always result in activism.

We approach the concept of safe space from a sociological perspective, acknowledging that safe spaces are not likely to be simple or singular in the social world. We interview young adults in Canada and the United States to discover their experiences of gay-straight alliances as safe spaces, to consider the qualities of safe spaces, and to understand their potential for supporting social change. As we discuss below, our model contains three dimensions of safe spacecontext, membership, and activities — which we capture with the following questions: safe from what? safe for whom? and safe for what activities?

On the one hand, the concept of safe space is too vague. It is applied post hoc to a wide variety of social spaces without consensus as to the qualities that make spaces safe (Polletta, 1999). On 
the other hand, sociologists have claimed that safe spaces are very powerful precursors to mobilization, even going so far as to claim that democratic movements require safe spaces (Evans and Boyte, 1986). By considering one type of safe space, the gay-straight alliance, in a wide variety of high schools throughout Canada and the United States, we put forth a conceptual framework that articulates key dimensions of safe spaces without assuming a priori that all these spaces are alike. In doing so, we offer a clear conceptual framework of safe spaces for social movement scholarship and highlight the qualities of gay-straight alliances that make them feel safe to LGBTQ students and their straight-identified allies.

\section{The need for safe spaces in high schools}

High schools can be sites of bullying and abuse for lesbian and gay youth, or for anyone who does not closely conform to traditional gender roles. Although this may be changing for the better over time, what little data exist on this topic show that anti-gay harassment is common. For example, the Gay, Lesbian and Straight Education Network (GLSEN) in the United States has run six surveys on high school climates between 1999 and 2009. The most recent report indicates that $61 \%$ of $\mathrm{LGBT}^{1}$ students feel unsafe and $72 \%$ hear derogatory remarks, while $85 \%$ are verbally harassed and $40 \%$ are physically harassed based on their sexual orientation (Kosciw, et al., 2010). In addition, almost $70 \%$ of U.S. transgender students have been verbally harassed in the previous year. GLSEN also notes that among LGBT students of colour, $80 \%$ were verbally harassed and 60\% were physically harassed (Diaz and Kosciw, 2009). Reports from Canada

\footnotetext{
${ }^{1}$ There is variation in terminology among research on LGBTQ issues. For example, the GLSEN surveys refer to LGBT students, while the Egale surveys refer to LGBTQ students. Other research uses the term queer to capture various dimensions of sexuality and gender identity. For accuracy, we adopt the terminology used by each study when referring to its findings, but we use the term LGBTQ when referring to our own findings or to student experiences in general.
} 
indicate that the school climate is also hostile. Findings from Egale Canada's first National Climate Survey on Homophobia include the following:

Three-quarters of LGBTQ students feel unsafe in at least one place at school, such as change rooms, washrooms, and hallways. Half of straight students agree that at least one part of their school is unsafe for LGBTQ students (Taylor et al., 2008).

The school climate for transgender students is even more difficult. Based on their recent survey, Egale Canada finds that $95 \%$ of transgender participants feel that their school is unsafe (Taylor, et al., 2008).

Given that LGBTQ youth are at greater risk of a host of social problems, including depression, suicide, dropping out of school, homelessness, and drug use (Birkett, Espelage and Koenig, 2009; Espalage, et al., 2008; Hatzenbuehler, 2011; Rotheram-Borus, Hunter, and Rosario, 1994; Russell, 2003), and that these youth are more likely to experience stress, conflict with their families, personal homonegativity, and sexual risk-taking (Carragher and Rivers, 2002; Saewyc et al., 2006; Williams, et al., 2005), the need for safe spaces for LGBTQ students in high schools is widely understood to be necessary and urgent (Russell, 2003; Szalacha, 2003). Gay-straight alliances are often put forth as the solution to LGBTQ students' distress (Stengel, 2010). Indeed, some studies of gay-straight alliances find that these student support groups improve the safety of LGBTQ students (Goodenow, Szalacha and Westheimer, 2006) and reduce depression and dropout rates (Toomey, et al., 2011). Gay-straight alliances also work to fracture heterosexual space in public schools (Grace and Wells, 2009), and they provide alternatives to heteronormative school activities such as the prom (Meyer, 2007). According to Wells (2006), gay-straight alliances aid in fostering an inclusive learning community that values diversity as essential to the creation of safe schools. Gay-straight alliances are also found to positively affect 
school experiences even for youth who are not group members (Walls, Kane and Wisneski, 2010). However, scholarship on this topic has yet to fully investigate the specific aspects of gaystraight alliances in particular that make the students feel safe (Stengel, 2010; Hackford-Peer, 2010; Weems, 2010).

\section{Thinking about Safe Spaces}

For decades, the sociological literature has used the concept "safe spaces" (or equivalent terms such as "free spaces," "protected spaces," "havens" or "free social spaces") to refer to "smallscale settings within a community or movement that are removed from the direct control of dominant groups, are voluntarily participated in, and generate the cultural challenge that precedes or accompanies political mobilization (Polletta, 1999: 1). Dozens of sociological studies of mobilization and activism have argued that these safe spaces produce counterhegemonic ideas and identities, thus building the resources that movements can mobilize

for collective action. The term "free space" was first used separately by Harry C. Boyte (1972) and by Sara Evans (1979) and elaborated more fully in their book, Free Spaces, in which they argue that these spaces "are the environments in which people are able to learn a new selfrespect, a deeper and more assertive group identity, public skills and values of cooperation and civic virtue" (Evans and Boyte, 1986: 17). In many cases, these safe spaces have resided in organizations just outside social movements; Morris (1984) calls them "movement halfway houses" to mark their status as both sheltered from dominant ideologies but not necessarily a part of a social movement. 
Safe spaces, according to numerous scholars, are very powerful sites. Polletta (1999: 4) points out that they allow for the convergence of major theoretical models in social movements theory, combining resource mobilization's focus on organizations and networks (e.g., McCarthy and Zald, 1977) with new social movement theory's concern for the cultural dimensions of activism (e.g., Melucci, 1989). Various scholars have claimed that safe spaces were crucial to developing strategies for the U.S. civil rights movement (Morris, 1984) at the same time that these spaces allowed women in that movement to develop radical feminist identities and ideologies (Evans, 1979; Robnett, 1997). "Havens," as Hirsch (1993) called them, allowed German workers in Chicago to build a radical labour movement, and Fantasia and Hirsch (1995) claim that these spaces led Algerian revolutionaries to reimagine the veil. In the U.S. women's movement, safe spaces are said to have birthed the movement (Mueller, 1994) and radicalized identities (Whittier, 1995). The most stalwart supporters of safe spaces argue that they are necessary to democratic social movement activity, even though they often operate on the margins of those movements (Evans and Boyte, 1986).

Despite the widespread application of this concept to a variety of movements across the globe, not all social movement theorists are convinced that this concept is sufficiently theorized. In particular, Francesca Polletta (1999) offers a threefold critique of "free spaces" as a concept: 1) that the term threatens to subsume culture under the realm of structure; 2) that the concept draws scholars' attention to physical spaces, rather than to the associational ties within those spaces; and - most relevant here-3) that the concept is so poorly specified that it has been applied in an overly broad, even self-contradictory, manner. Polletta addresses these critiques in part by constructing a schema by which different types of free spaces - trans-movement, indigenous, and 
prefigurative - are assigned to different roles in mobilization. She also cautions theorists to clarify the cultural processes that emerge from these spaces. Other scholars have issued similar criticisms and echoed this call for specificity (see Anzaldúa, 2002; Hackford-Peer, 2010; Hammers, 2009; Stengel, 2010; Stotzer, 2010).

Despite this critical evaluation of the concept, scholars in sociology and elsewhere have continued to use the term safe spaces uncritically, assuming that these spaces are easy to identify as well as assuming rather than demonstrating their liberating or democratizing effects. Some sorts of spaces are taken for granted to be safe spaces for marginalized groups: autonomous, voluntary organizations somewhat outside the surveillance of dominant structures. Gay-straight alliances are one such space. In the literatures of education, youth, and sexuality, gay-straight alliances are often named as safe spaces for high school students (e.g., Wells, 2006; Walls, Kane and Wisneski, 2010).

In Polletta's (1999) scheme, gay-straight alliances occupy a prefigurative safe space characterized by symmetrical associational ties. Such a space, according to this model, is external to the movement itself, but has the capacity to develop new identities and claims, as it tries to live out its ideologies of equality and justice in the real world. These safe spaces accomplish these goals by providing some shelter from dominant ideologies, by creating physical (or virtual) spaces for like-minded people to meet and engage in dialogue, and by building skills for leadership or other activist roles. We build on Polletta's insights by identifying three important dimensions within this pre-figurative category along which the characteristics of safe spaces can vary: contexts, membership, and activities. 
The first of our questions, safe from what?, examines the contexts in which safe spaces are created. Stengel (2010: 507) claims that safe spaces are "deeply connected to affective states." She argues that when we consider safe spaces, we must also consider the role of fear. This echoes early studies of safe spaces, which tend to focus on settings ripe with potential violence, such as some towns in the U.S. South during the civil rights movement (Morris, 1984). The dimension of context questions how levels of violence, harassment, discomfort, and social exclusion are a central component of theorizing safe space.

The second of our questions, safe for whom?, inquires about membership inclusivity or exclusivity. Polletta and Jasper (2001) consider the role of free space vis-à-vis boundary maintenance and collective identity development. Groch (2001) claims that oppositional identities require safe spaces, claiming directly that members-only retreats from hegemonic views are a necessary feature of safe spaces. Hackford-Peer (2010) examines fear, exclusivity and gay-straight alliances, claiming that students of colour do not feel safe in these groups. The dimension of membership focuses on how our participants enacted boundary maintenance through inclusion and exclusion of members.

The third of our questions, safe to do what?, considers the relationship between safe spaces and the actions that emerge from them. This question interrogates the social movements literature's assumption that safe spaces are the incubators of collective action. This body of work makes a strong case that safe spaces are not only important sites to protect marginalized groups, but also to foster activism. It connects safe spaces with many of the social processes considered essential 
for mobilization. In this regard, Polletta (1999) considers the link between free spaces and collective identity building. Morris (1984) emphasizes their institutional and cultural supports for activism. The dimension of activities requires our participants to reflect on the kinds of actions that emerge from these spaces. Whether or not the safe spaces of gay-straight alliances will produce activism is an empirical question that we address directly in this study.

Our goal here is to add clarity to the scholarly discourse on safe spaces without imposing artificial limits on what types of spaces might be considered safe spaces. To do this, we extract these three dimensions from the scholarly discussion of safe spaces and hold them up for empirical review by asking our participants to remark on their particular experiences with gaystraight alliances in high schools. In doing so, our contribution is two-fold. First, we add to social movement theory's discourse on safe spaces by offering a schematic that clarifies the key components of safe spaces while focusing on both the structural and cultural components of safe spaces. Second, we contribute to the study of gay-straight alliances as an important site of struggle for LGBTQ youth and their straight-identified allies.

\section{Methods}

Between 2005 and 2008, we conducted 57 online interviews with young adults, ages 18-25, who had participated in gay-straight alliances or similar LGBTQ groups in high school. Of the 57 respondents, 38 were involved in a gay-straight alliance in their high school, while the other 19 were involved in similar school-based LGBTQ activism. Interviews were semi-structured, with consistent interview questions across participants as well as open-ended questions and invitations 
for participants to add other information. ${ }^{2}$ Recruitment involved multiple snowball samples born from a variety of social networks of LGBTQ youth and adults across the United States and Canada. Of the 57 participants, 26 went to high school in the United States and 31 in Canada.

Table 1 lists the identifiers that participants provided; participants were allowed to use their own language to describe their gender and sexuality.

\section{[TABLE 1 ABOUT HERE]}

Participants were interviewed online via instant messaging software, such as iChat and MSN Messenger. To be sure that our sample included those who had closeted sexual identities during high school, we interviewed young adults (18-25 years of age) and asked them to reflect back on their experiences in high school. We chose instant messaging to broaden the geographic reach of our sample, which includes participants throughout Canada and the United States (for a discussion of qualitative interviews using instant messaging technology, see Kazmer and Xie, 2008). Pseudonyms were assigned to all participants and others they referred to during the interviews. Identifying details were eliminated or slightly changed. Excerpted quotes were edited only for brevity; they are presented verbatim, including grammar and spelling errors. ${ }^{3}$ We used a systematic approach to coding the data. Two of the authors coded the themes independently, later meeting with a third author to discuss the areas of overlap and address issues of consistency. The two coders then produced a coding schema that resulted from this discussion. Later, a fourth

\footnotetext{
2 This project was approved by the McMaster University Research Ethics Board, project 2005073.

${ }^{3}$ Several of our participants typed ellipses to indicate pauses in thought. To distinguish these ellipses in the original instant-messaging transcripts from our edits, we use a bracketed ellipsis, [...], to indicate an edited section of the text. We also use a slash, /, to indicate a break between instant messaging transmissions.
} 
author independently coded the data as well to guarantee consistency of coding and to strengthen the reliability of the findings.

Although the literature provides us with a basic foundation for understanding safe spaces, the lack of specificity in this discourse calls for a clearer and more specific conceptual framework. Our analytical approach begins with insights from the scholarly literature and asks participants to comment on their subjective experiences in their gay-straight alliance groups. Our analysis then synthesizes, organizes and elaborates upon their thoughts on safe spaces, using the existing sociological scholarship on this topic to guide our process. Although the research design allows for a cross-national comparison, the similarities across national contexts were striking. Thus, our analytical approach was to build one model applicable to both nations.

\section{Findings}

We asked participants to comment on three elements of their experiences in gay-straight alliances. First, we asked about the hostile climate toward gay, lesbian, and gender variant students in school, as well as within families of origin and the larger community that created the social context that defined the need for safe spaces. Second, issues of membership ${ }^{4}$ of gaystraight alliances and the subculture that these organizations fostered were a key component of safety. And third, we asked participants to comment on the ways that gay-straight alliances allowed students to engage in educational activities and activism on behalf of LGBTQ students. Below, we present the responses of our participants, as they speak to these three dimensions of safe spaces: safe from what? safe for whom? and safe for what activities?

\footnotetext{
${ }^{4}$ In the context of this study, 'membership' and 'members' are meant informally, indicating involvement in a group or club, which may or may not also involve adoption of a social identity (Warner, Hornsey and Jetten, 2007).
} 


\section{Safe from What? Contexts for Safe Spaces}

The first dimension of safe space is the level of hostility and even danger in the social context where this space is situated. Both the literature on safe spaces and the responses from our participants indicate that the perceived level of hostility or insecurity of the environment is a key factor in participants' need for safe spaces. Barriers to the formation of gay-straight alliances came from contexts both internal and external to the schools. Some school boards, parents, administrators and fellow students opposed the formation of gay-straight alliances. This is not surprising, given that there has been a tendency for the education system to problematize and exclude homosexuality from its domain (MacDougall, 2000: 100). The marginalization of homosexuality within the school system is evident in both the Canadian and American contexts.

In our study, subjects pointed out that the efforts of opponents kept some gay-straight alliances from being officially recognized. Some students formed groups informally or outside school. In other cases, students succeeded in forming gay-straight alliances and equity and/or diversity groups despite this opposition.

[The biggest accomplishment] was being able to finally do things within the school [...] before that we couldn't even advertise [...] we couldn't do this when administration kept us underground (Jamie, bisexual, transgender)

The struggles of this student proved worthwhile when a new administration came into the school and allowed the gay-straight alliance to become an official school club. Other participants report similar struggles, with teachers or members of the administration actively involved in either stopping the creation of the gay-straight alliance or trying to shut it down after it started: 
well actually it had a huge impact on people at first, because the administration didn't want a GSA there, and then we had to get student support together and petition but then the administration gave up and our school newspaper wrote about the struggle we had / it was a big deal at the time even though we didn't think it was (Morgan, pansexual, no gender identity)

The climate at some schools was such that student organizations in support of LGBTQ issues were not allowed to call themselves gay-straight alliances and instead had to use generic names that made invisible their connection to lesbian and gay students. There were at least five Canadian LGBTQ groups in our sample that were unable to call themselves gay-straight alliances and were forced to broadly identify as "equity and diversity" groups.

Once a group was formed, many alliance members faced limits on their ability to promote events, finding their posters were subject to vandalism:

when we were advertaising [...] we had to put up our posters again each day because they were being torn down. We got our own board now, but it had to be in a place where there was a camera because our stuff was still be vandelized and torn down. (Catherine, pansexual, female)

This incident was echoed by a student at another school, who states: "When the posters for the GSA first went up, they were torn down and spit upon" (Patrick, male, straight). Some students found that their participation in gay-straight alliances provoked a backlash, making visible some of the hostility to LGBTQ people that had previously been hidden. For example:

the day after [an event sponsored by the gay-straight alliance,] their was tagging on the front of the school and the sidewalk between buildings / anti-gay comments / many people were accused of being gay who participated too... (Jaime, bisexual, transgender)

The safe space of a gay-straight alliance student club is bounded by the structure of school regulations, the policy decisions of school authorities, and the cultural climates that vary greatly in their acceptance of LGBTQ students. In addition to these administrative challenges in the 
formation of gay-straight alliances, students also experienced verbal harassment and physical abuse from their peers, teachers, administration and parents. Anti-gay graffiti appears to be a common struggle that many LGBTQ youth in our study dealt with at school. The following participant states: "[...] I generally kept to the theatre room [...] there did seem to be a lot of homophobic graffiti around whenever I ventured into the rest of the school" (Becky, queer, female). In some cases, peers created an anti-gay culture through verbal harassment and physical abuse. For example, one participant recalls:

Also, a majority of people in my school are very into the whole 'that's so gay' thing. And the whole calling people 'faggots' and 'queers'. They say they don't mean it in a negative way towards gay people... But if you think about it, that's exactly what they're saying. (Melissa, pansexual, female)

Coupled with these day-to-day instances of verbal abuse were instances of physical harassment by peers, including rape:

well [friend $\mathrm{X}$ ] had some verbal harassment... actually a lot of it from what i remember, both inside and outside of school. at one point, he was raped. (Michelle, lesbian, female)

I remember one meeting [...] one of the new members asked if he could speak, and divulged that he had been raped by another student at the school and was trying to decide whether or not to tell the police. I mean, you can't have that kind of experience and not be significantly changed for life. (Ryan, gay, male)

Instead of addressing issues of harassment, teachers were often the source of anti-gay harassment. In some cases, this took the form of ongoing harassment, such as running jokes at the expense of LGBTQ students:

that class had a running gag about lindsey lohan, so they had a calendar of her up in the classroom / there was one [picture] where she was not conservatively clad, and the teacher took it and went up to him (while he was sitting) and he was like "this doesn't do *anything* for you???" [...] then there were jokes from classmates and that sort of thing (Jason, queer, male) 
At other times, harassment from teachers involved physically separating students they believed to be dating or intimately involved.

The hostile climate found in many schools also extended beyond the confines of high school, into the families and communities of many respondents. Not only did participants encounter difficulties with their parents accepting their sexuality, but some were also discouraged from hanging out with LGBTQ friends.

I: Did anyone ever give you a hard time for hanging out with any of your gay/queer/bi/lesbian friends?

R: well...my mom does [...] its gotten bad lately and i'm moving out from it [...] she's having issues with my hanging out with gay friends all the time (Jaime, bisexual, transgender)

The larger community also posed problems for the following participant, who lived in a city in the United States that he described as "ultra-conservative:"

My high school [...] had invited the founder of the city's PFLAG [Parents, Families, \& Friends of Lesbians and Gays] organization to speak to students. Well, some alumni [...] held a protest vigil across the street from the school because of their "concern" that the school was promoting "homosexuality" through the religion curriculum. (Quinn, queer, gender variant)

The participant adds, "[t]he anti-gay vigil organizers also brought in at least two anti-gay national personalities and ex-gay types who spoke on some conservative (but popular) talk radio programs in [large city]." The vigil did spark conversation among students who felt a need for a supportive network or club where they could connect. This participant and some fellow students formed an underground "dance club," basically, their version of a gay-straight alliance. However, their club was later investigated for "promoting homosexuality." 
Participants connected their experiences with anti-gay comments both within school and in the larger community with a need for safe spaces, and just about everyone we interviewed indicated that gay-straight alliances did provide the kind of safe spaces they needed to withdraw from this hostile climate. For example, one participant suggests,

We all need a sanctuary. I'm extremely grateful I was involved since it [the gay-straight alliance] helped me come to terms with being different. (Amanda, asexual, female)

Given the verbal and physical forms of harassment that students encountered from fellow students, teachers and administrators, and the pressures from family and friends, gay-straight alliances and other LGBTQ organizations did indeed provide a safe space from internal and external threats to their safety. In addition, we found evidence of a connection between the amount of hostility in the school—-from administrators, teachers or fellow students — and both the type of safe space and the meaning of that space to group members. For example, extremely hostile contexts, in which there was a strong consensus in anti-gay opinions, such as in private religious schools or conservative towns, contained groups that were underground rather than official, in which members were closeted. In these cases, our participants reported deeply felt ties to fellow group members and to the group itself.

\section{Safe for Whom? Membership in Safe Spaces}

The second dimension of safe spaces is membership - who is welcome and who is left out. As collective identity formation is a key cultural process associated with safe spaces in the scholarly literature (e.g., Polletta and Jasper, 2001; Robnett, 1997; Whittier, 1995), membership in gaystraight alliances is an important site of boundary maintenance. In our interviews, we asked participants to speak directly to the issue of membership in gay-straight alliances. Previous 
research on gay-straight alliances and safety have clearly illustrated how gay-straight alliances and other LGBTQ organizations may be safe for some students while unsafe for others (Griffin et al., 2004; McCready, 2001). For example, one student notes that not all identities were acknowledged in the gay-straight alliance she helped form:

we didn't really acknowledge the T in LGBTQ...it was [a] GSA and that had no room for people with different gender identities...not that we hated trans people, but that we felt there was no one on campus that could possibly fit that letter and so didn't acknowledge that we might be wrong, that there could have been someone out there with gender identity issues (Morgan, pansexual, no gender identity)

Furthermore, many students in gay-straight alliances were unwilling to disclose their sexual identities during meetings. They feared repercussions from fellow students:

actually, really hilariously, no one really identified themselves because if we did, it would go around the school and someone might be harrassed by other students (Morgan, pansexual, no gender identity)

One of our more surprising findings was the large extent to which participants hailed the sexual diversity of the group as a positive aspect of the safe space that the group created. In particular, the role of straight students, which might be expected to undermine the sense of community and solidarity among LGBTQ students, was for the most part lauded as a particularly useful, helpful, or encouraging aspect of the gay-straight alliance. For example, one queer man says:

I don't know what the straight/non-straight breakdown of that group was, but I was happy that a striaght guy was willing to be out front in support of queer issues (Mark, queer, male)

For others, the inclusion of straights was seen as a way to make connections and educate the larger heterosexual community:

umm to go back to the straight people being involved in a GSA, I also think that they need to be there because the gay community needs a sort of bridge if you will between them and the heterosexual community, and these straight members act as that bridge (Jen, bisexual, female) 
The inclusion of straight allies in the club provided cover for students who were not ready to disclose their sexual identity, or who were questioning their sexual identity. Straight allies were crucial to creating a space in which closeted kids could participate. As one respondent notes:

I think that in larger schools [...] the closet became less of an issue because the group was large enough that it made sense that some extremely confident straight kids might be involved--so they could still be involved and even lead without that label being implicit [...] So just having out kids may have made it easier for closeted kids to be involved. (Logan, gay, male)

Another important aspect to note is that all of the LGBTQ participants in our study were pleased by the support and involvement of straight allies. This participant sums up the common sentiment:

Because any queer will stand up for their own rights. But when you can get a straight person to fight and be vocal for a right that doesn't affect them and that sometimes, they don't even really understand? well / it kind of made the 'ally' part of the GSA really. (Lisa, lesbian, female)

Our respondents make clear that, while they felt that gay-straight alliances were safe spaces for themselves, there was not necessarily a full range of students participating in these groups. In particular, students of color were not present in great numbers, and racism was raised as a discussion topic more often among those student groups that were designated as diversity or antioppression groups rather than as gay-straight alliances. While this was disappointing to some of our respondents who felt that their LGBTQ identities were being made invisible, it also seemed to bring greater attention to racism. In terms of membership, students of color and trans students were most likely to be marginalized in these groups, while straight students were welcomed.

Safe to Do What? Activities Emerging from Safe Spaces

Our third question considers the kind and quality of activities that gay-straight alliances produce. This is especially salient to the social movement literature, which is concerned less with the 
quality of the space than with its potential to mobilize participants. Our respondents describe how gay-straight alliances opened the door for a number of activities aimed at raising awareness of LGBTQ people and educating others about difference, but that gay-straight alliances did not create much policy change in their schools and communities.

In spite of the previously noted pressures from principals, the administration, parents' associations and other students, there were many gay-straight alliances in schools that were able to promote a wide range of activities. For example, the "day of silence" and "pride prom" were events held by gay-straight alliances at some high schools in order to raise awareness of LGBTQ issues. During the "day of silence," participants refuse to speak for the day to draw attention to the cultural silence around LGBTQ issues. As this participant explains:

It [the day of silence] has brought gay rights to the forefront of our minds, and has opened people's eyes about GLBT people. We have become a more tolerant, open school, partially as a result of this. (Katie, bisexual, female)

Other activities included students making pro-gay buttons, which students at one U.S. high school created in addition to participating in the day of silence, as this student discusses: but $i$ think recognizing the day of silence and wearing pro-gay rights buttons that we made ourselves to show our support in getting rid of the anti-gay marriage amendment was what hit our school the hardest as far as proud impact on young minds (Morgan, pansexual, no gender identity)

For this student, the issue of gays being able to marry was about freedom of choice, as well as the possibility of marrying and having children someday, which this participant equates with the ability to lead "a normal, young life." This demonstrates students' persistence and their effectiveness at drawing attention to larger issues within their school community. The distribution of "slurring tickets" was another creative idea, as this student describes: 
"we collaborated and made these explainations of why its offensive to use terms like 'gay' to refer to anything that's 'bad'... we all give them out to make our point but to avoid being put on the spot" (Megan, bisexual, female).

Efforts of other students extended beyond their immediate high school to reach students from other high schools. In one Canadian city, students threw a "pride prom," which LGBTQ students from various high schools could attend. As many schools forbid students from bringing same-sex dates to the prom, the students involved felt this was a much-needed act of inclusion:

the fact that we threw the first EVER Rainbow Prom :) [was especially important] because a lot of my friends couldn't bring whot hey wanted to their proms. ours was not only veryyy affordable for kids who no longer live at home for whatever reason, but you could obviously bring any date you wanted :) (Ashley, bisexual, female)

Other gay-straight alliance members participated in activities that benefitted the larger community. This included raising supplies for a local women's shelter, starting an AIDS fundraising campaign, participating in and raising money through AIDS walks, assisting in the development of education packages for a local school board, and publishing an article regarding LGBTQ issues in local newspaper. Perhaps one of the most ambitious activities was carried out by students at one U.S. high school who were able to organize a state-wide gay-straight alliance conference:

The biggest single-event thing was holding a GSA conference for any schools in the state. [...] We brought in presenters from all kinds of different organizations in the city, had keynote speakers, all kinds of things. It was absolutely amazing. (Ryan, gay, male)

Students involved in gay-straight alliances were instrumental in planning and carrying out a variety of activities, many of which brought a profound sense of accomplishment to those involved. Through the support of other students, teachers and administrators, these students felt empowered to engage in education and activism, in addition to social activities. This does not 
discount the fact that for many students who were involved in gay-straight alliances, the social support garnered through their involvement was satisfying on its own. For many, the sheer existence of the group and access to a comfortable social space was what made high school a bearable experience. As this account demonstrates:

We accomplished permanent and dedicated members. What I was proud of was the dedication of those members who came every week and brought their friends along with a smile and were always ready to do whatever activity was planned (Mike, gay, male)

The safe spaces of gay-straight alliances, however, failed to achieve many of the goals that participants had for their groups. When asked what kind of impact the gay-straight alliance had on the school, one student who had founded a gay-straight alliance in his school replied: "to tell the truth not much" (Jack, gay, male). When asked why, this participant spoke of the newness of this gay-straight alliance and the students' self-professed lack of organization in planning events. So, while many students wanted their alliance to create an LGBTQ-friendly school, to reverse some heterosexist policies like restricting prom dates by gender, or to launch some activism in their larger communities, this was seldom possible among our respondents. Overall, gay-straight alliances provided opportunities for limited activism, social exchange, and dialogue, though the kind and quality of activities produced in these spaces greatly varied depending on external factors (such as pressures from parents' groups) and internal factors (such as pressures from administrators, principals and students), in addition to the unique demands and concerns of the gay-straight alliance members.

\section{Discussion}

The concept of safe spaces is useful to sociologists who study social movements as a way to understand where heterodox ideas and collective identities emerge. These resources are central to 
mobilization, and scholars have claimed that safe spaces are the places where these radical cultural products are created. However, as Polletta (1999) and others have noted, this concept is under-theorized. As a vague notion rather than a clear conceptual framework, this idea is applied in widely varying, even self-contradictory ways. Our research addresses this shortcoming of safe spaces by focusing on gay-straight alliances as one important case of safe space to develop a conceptual framework that clearly specifies three dimensions of safe space.

The three dimensions we put forth are context (safe from what?), membership (safe for whom?), and activity (safe to do what?). Safe spaces can vary along each of these dimensions to produce a wide variety of social settings, all of which feel like safe spaces to our participants. In addition, we suggest that these dimensions interact with each other to shape safe spaces. More hostile contexts, for example, are likely to restrict membership practices and the activities in which students participate. Further research should be conducted on how the dimensions of context, membership and activity may contribute to a better understating of safe spaces in and around other social movement organizations, such as anti-poverty groups, social justice groups, feminist groups, LGBTQ groups, anti-racism groups, among others. These three dimensions will add much-needed specificity to the concept while remaining flexible enough to apply to a wide variety of spaces.

We also consider the extent to which the safe spaces produced by gay-straight alliances mobilize students and encourage activism, as the social movement literature would claim. We find that activism is not the inevitable outcome of gay-straight alliances. High schools' concerns with discipline and order, and especially their restrictive policies on student behavior, limited the 
activities that were feasible or even imaginable among our participants. This finding suggests that social movement scholars cannot assume a priori that safe spaces lead to mobilization.

Our study also deepens our knowledge of gay-straight alliances in high schools across Canada and the United States. This growing body of work on gay-straight alliances considers the extent to which these groups reduce stress on LGBTQ students, eliminate bullying, improve LGBTQ dropout rates, or prevent LGBTQ teen suicides. Our study demonstrates that gay-straight alliances are not all the same. The wide variety of experiences reported by our participants serves as a useful reminder that consideration must be given not only to whether high schools have gaystraight alliances, but also to the variation in the qualities of these groups and the safe spaces they create for LGBTQ students and their straight allies. 
Table 1: Breakdown of participants

\begin{tabular}{|c|c|c|c|c|}
\hline Gender & Sexual Identity & $\begin{array}{c}\text { Race and/or } \\
\text { ethnicity }\end{array}$ & Nation & Involvement \\
\hline 29 female & 18 gay & 35 White & 31 Canada & $\begin{array}{l}38 \text { gay-straight alliance } \\
\text { recognized by school }\end{array}$ \\
\hline 23 male & 7 lesbian & 1 Black & 26 United States & $\begin{array}{l}19 \text { informal or external } \\
\text { LGBTQ group }\end{array}$ \\
\hline 2 transgender & 4 homosexual & 3 Asian & & \\
\hline 1 all genders & 10 bisexual & 1 Hispanic & & \\
\hline $\begin{array}{l}1 \text { gender } \\
\text { variant }\end{array}$ & 5 straight & 2 Jewish & & \\
\hline \multirow[t]{4}{*}{1 no response } & 5 queer & 1 Armenian & & \\
\hline & 3 pansexual & 8 mixed background & & \\
\hline & 2 asexual & 4 no response & & \\
\hline & 2 heterosexual & & & \\
\hline
\end{tabular}




\section{Works Cited}

Anzaldúa, G. E. 2002. "(Un)natural bridges, (Un)safe spaces." In This Bridge We Call Home: Radical visions for transformation, edited by G. E. Anzaldúa and A. Keating, pp. 1-5. New York, NY: Routledge.

Birkett, M., D. L. Espelage, and B. Koenig. 2009. "LGB and Questioning Students in Schools: The Moderating Effects of Homophobic Bullying and School Climate on Negative Outcomes.” Journal of Youth and Adolescence 38: 989-1000.

Boyte, H. C. 1972. “The Textile Industry: Keel of Southern Industrialization.” Radical America 6(2): 4-49.

Carragher, D. J., and I. Rivers. 2002. "Trying to Hide: A Cross-National Study of Growing Up for Non-Identified Gay and Bisexual Male Youth." Clinical Child Psychology and Psychiatry 7(3): 457.

Cortese, D. K. 2006. Are We Thinking Straight? The Politics of Straightness in a Lesbian and Gay Social Movement Organization. New York, NY: Routledge.

Cruz, C. 2008. "Notes on Immigration, Youth, and Ethnographic Silence." Theory Into Practice 47: 67-73.

Diaz, E. M., and J. G. Kosciw. 2009. Shared Differences: The Experiences of Lesbian, Gay, Bisexual, and Transgender Students of Color in Our Nation's Schools. New York, NY: GLSEN.

Espelage, D. L., S. R. Aragon, M. Birkett, and B. W. Koenig. 2008. "Homophobic Teasing, Psychological Outcomes, and Sexual Orientation among High School Students: What Influence Do Parents and Schools Have?" School Psychology Review 37: 202-216. 
Evans, S. M. 1979. Personal Politics: The Roots of Women's Liberation in the Civil Rights Movement and the New Left. New York, NY: Vintage Books.

Evans, S. M., and H. C. Boyte. 1986. Free Spaces: The Sources of Democratic Change in America. New York, NUY: Harper and Row.

Fantasia, R., and E. L. Hirsch. 1995. "Culture in Rebellion: The Appropriation and Transformation of the Veil in the Algerian Revolution." In Social Movements and Culture, edited by H. Johnston and B. Klandermans, pp. 144-162. Minneapolis, MN: University of Minnesota Press.

Fetner, T., and K. Kush. 2008. "Lesbian and Gay Activism in High Schools: The Emergence of Gay-Straight Alliances.” Youth and Society 40: 114-140.

Goodenow, C., L. Szalacha, and K. Westheimer. 2006. "School Support Groups, Other School Factors, and the Safety of Sexual Minority Assaults." Psychology in the Schools 43: 573589.

Grace, A. P., and K. Wells. 2009. "Gay and Bisexual Male Youth as Educator Activists and Cultural Workers: The Queer Critical Praxis of Three Canadian High-School Students." International Journal of Inclusive Education 13: 23-44.

Griffin, P., C. Lee, J. Waugh, and C. Beyer. 2004. "Describing Roles that Gay-Straight Alliances Play in Schools: From Individual Support to School Change.” Journal of Gay and Lesbian Issues in Education 1: 7-22.

Groch, S. 2001. "Free Spaces: Creating Oppositional Consciousness in the Disability Rights Movement." In Oppositional Consciousness: The Subjective Roots of Social Protest, edited by J. J. Mansbridge and A. Morris, pp. 65-98. Chicago, IL: University of Chicago Press. 
Hackford-Peer, K. 2010. "In the Name of Safety: Discursive Positionings of Queer Youth." Studies in Philosophy and Education 29: 541-556.

Hammers, C. 2009. "Space, Agency, and the Transfiguring of Lesbian/Queer Desire." Journal of Homosexuality 56: 757-785.

Hatzenbuehler, M. L. 2011. "The Social Environment and Suicide Attempts in Lesbian, Gay, and Bisexual Youth." Pediatrics 127: 896-903.

Hirsch, E. L. 1993. "Protest Movements and Urban Theory." Research in Urban Sociology 3: 159-180.

Kazmer, M. M., and B. Xie. 2008. "Qualitative Interviewing in Internet Studies: Playing with the Media, Playing with the Method." Information, Communication and Society 11(2): 257278.

Kosciw, J. G., E. A. Greytak, E. M. Diaz, and M. J. Bartkiewicz. 2010. The 2009 National School Climate Survey: The Experiences of Lesbian, Gay, Bisexual and Transgender Youth in our Nation's Schools. New York, NY: GLSEN.

Lee, C. 2002. "The Impact of Belonging to a High School Gay/Straight Alliance.” The High School Journal 85: 13-26.

MacDougall, B. 2000. Queer Judgments: Homosexuality, Expression and the Courts in Canada. Toronto, ON: University of Toronto Press.

McCarthy, J. D., and M. N. Zald. 1977. "Resource Mobilization and Social Movements: A Partial Theory." American Journal of Sociology 82(6): 1212-1241. 
McCready, L.T. 2001. "When Fitting In Isn't an Option, or Why Black Queer Males at a California High School Stay Away from Project 10." In Troubling Intersections of Race and Sexuality, edited by K. Kushamiro, pp. 37-54. Lanham, MD: Rowman and Littlefield.

Melucci, A. 1989. Nomads of the Present: Social Movements and Individual Needs in Contemporary Society. Philadelphia, PA: Temple University Press.

Meyer, E. 2007. "'But I'm Not Gay': What Straight Teachers Need to Learn about Queer Theory." In Queering Straight Teachers: Discourse and Identity in Education. Complicated Conversation: A Book Series of Curriculum Studies, edited by N.M Rodriguez and W. F. Pinar, pp. 1-17. New York, NY: Peter Lang.

Miceli, M. 2005. Standing Out, Standing Together: The Social and Political Impact of GayStraight Alliances. New York, NY: Routledge.

Morris, A. 1984. The Origins of the Civil Rights Movement: Black Communities Organizing for Change. New York, NY: Free Press.

Mueller, C. McClurg. 1994. "Conflict Networks and the Origins of Women's Liberation." In New Social Movements: From Ideology to Identity, edited by E. Laraña, H. Johnston, and J. R. Gusfield, pp. 234-263. Philadelphia, PA: Temple University Press.

Polletta, F. 1999. “'Free Spaces' in Collective Action.” Theory and Society 28: 1-38.

Polletta, F. and J. Jasper. 2001. "Collective Identity and Social Movements." Annual Review of Sociology 27: 283-305.

Robnett, B. 1997. How long? How long? African-American Women in the Struggle for Civil Rights. Oxford, UK: Oxford University Press. 
Rotheram-Borus, M. J., J. Hunter, and M. Rosario. 1994. "Suicidal Behavior and Gay-Related Stress among Gay and Bisexual Male Adolescents." Journal of Adolescent Research 9: 498-508.

Russell, S. T. 2003. "Sexual Minority Youth and Suicide Risk." American Behavioral Scientist 46(9): 1241-1257.

Saewyc, E. M., C. L. Skay, S. L. Pettingell, E. A. Reis, L. Bearinger, M. Resnick, A. Murphy, and L. Combs. 2006. "Hazards of Stigma: The Sexual and Physical Abuse of Gay, Lesbian, and Bisexual Adolescents in the United States and Canada." Child Welfare 85: $195-213$.

Stengel, B. S. 2010. "The Complex Case of Fear and Safe Space." Studies in Philosophy of Education 29: 523-540.

Stotzer, R. 2010. "Seeking Solace in West Hollywood: Sexual Orientation-Based Hate Crimes in Los Angeles County." Journal of Homosexuality 57: 987-1003.

Szalacha, L. 2003. "Safer Sexual Diversity Climates: Lessons Learned from an Evaluation of Massachusetts Safe Schools Program for Gay and Lesbian Students.” American Journal of Education 110: 58-88.

Taylor, C., T. Peter, K. Schachter, S. Paquin, S. Beldom, Z. Gross, and T. L. McMinn. 2008. Youth Speak Up about Homophobia and Transphobia: The First National Climate Survey on Homophobia in Canadian Schools. Phase One Report. Toronto, ON: Egale Canada Human Rights Trust. 
Toomey, R. B., C. Ryan, R. M. Diaz, and S. T. Russell. 2011. "High School Gay-Straight Alliances (GSAs) and Young Adult Well-Being: An Examination of GSA Presence, Participation, and Perceived Effectiveness." Applied Developmental Science 15(4): 175185.

Walls, N. E., S. B. Kane, and H. Wisneski. 2010. “Gay-Straight Alliances and School Experiences of Sexual Minority Youth.” Youth and Society 41: 307-332.

Warner, R., M. Hornsey, and J. Jetten. 2007. "Why Minority Group Members Resent Imposters." European Journal of Social Psychology 37: 1-17.

Weems, L. 2010. "From 'Home' to 'Camp': Theorizing the Space of Safety." Studies in Philosophy of Education 29: 557-568.

Wells, K. 2006. Gay-Straight Alliance Handbook: A Comprehensive Resource for Canadian K12 Teachers, Administrators and School Counsellors. Ottawa, ON: Canadian Teachers' Federation.

Whittier, N. 1995. Feminist Generations: The Persistence of the Radical Women's Movement. Philadelphia, PA: Temple University Press.

Williams, T., J. Connolly, D. Pepler, and W. Craig. 2005. "Peer Victimization, Social Support, and Psychosocial Adjustment of Sexual Minority Adolescents." Journal of Youth and Adolescence 34: 471-482. 